\title{
Peran Didikan Orang Tua Dan Lingkungan Sosial Terhadap Pembentukan Kepribadian Anak Tinjauan Aliran Konvergensi
}

\author{
Yagung Maiwanly, Balang Hengki Kristian, Gifta Eunike Patty, Reallya Yemima
}

\begin{abstract}
ABSTRAK
Pendidikan anak dalam keluarga dan lingkungan akan berpengaruh dalam pembentukkan kepribadian anak, dimana orang tualah yang pertama menanamkan nilai-nilai pendidikan yang benar kepada anak dan lingkungan sosial tempat mereka dapat mengembangkan nilai-nilai pendidikan yang telah diajarkan. Dalam penulisan ini bertujuan untuk melihat sejauh mana metode 5P ini dapat dikembangkan di dalam ruang lingkup keluarga dan lingkungan sosial. Hal ini juga bertujuan dalam melihat perkembangan apa yang akan di alami anak, ketika ia berada di lingkungan sosial apakah ia mampu menyesuaikan diri dengan lingkungan sekitarnya, dan apakah ia mampu mengembangkan bakat yang di milikinya sehingga anak bisa mencapai prestasi yang baik. Penulisan di tulis untuk melihat sejauh mana peran lingkungan kelurga dan lingkungan sosial berpengaruh dalam pembentukan kepribadian anak.
\end{abstract}

Kata-kata kunci: anak, konevergensi, peserta didik, guru, kepribadian

\section{PENDAHULUAN}

Pendidikan adalah sebuah kebutuhan dalam membantu mengembangkan potensi dan bakat yang di miliki oleh seorang anak, dan pendidikan juga merupakan sebuah usaha sadar dan terencana demi terwujudnya proses belajar. anak merupakan karunia dari Tuhan yang diberikan kepada orang tua untuk di pertanggung jawabkan dan di berikan pendidikan. Orang tua sangat berpengaruh penting terhadap perkembangan anak, sebab orang pertama yang dekat dengan anak adalah orang tua. salah satu tujuan orang tua yang ingin di capai dalam diri anaknya adalah membuat mereka menjadi anak yang mandiri dan dapat bertanggung jawab.

Pendidikan anak bukan hanya ada di sekolah namun juga ada di lingkungan keluarga. Didikan orang tua merupakan dasar untuk pembentukan kepribadian anak, sehingga dapat di katakan bahwa pendidikan ini terjadi dari banyak arah. Keluarga adalah persekutuan kecil untuk proses pendidikan anak di mana anak dapat berinteraksi kepada orang tua dengan baik. Anak adalah tanggung jawab orang dewasa, dalam kebutuhan holistic anak sehingga anak dapat bertumbuh dengan kepribadian yang baik. Kebutuhan anak yang paling mendasar adalah keluarga, salah satunya adalah didikan orang tua dalam menjaga anak agar tetap berada pada jalan yang Tuhan inginkan dan tanggung jawab orang tua adalah menjaga anak. Sekolah merupakan wadah penting bagi kebutuhan untuk 
mengaktualisasikan diri, karena di sekolahlah tempat yang tepat untuk mengembangkannya.

Pendidikan yang diberikan kepada anak di dalam rumah seharusnya tidak terlalu menekan pada diri anak, seharusnya dapat memberikan kesempatan kepada anak untuk menjalani kehidupannya tanpa adanya pemaksaan dari kedua orang tuanya. Karna kalau adanya pemaksaan yang berlebihan terhadap anak, anak akan patuh kepada orang tuanya saja tetapi ketika dia tidak berada di samping orang tuanya dia akan menjadi anak yang tidak patuh. Anak juga akan bertumbuh menjadi anak yang tidak percaya diri dan juga kehilangan jati diri yang sesungguhnya. Lebih baik orang tua mendidik anak dengan cara yang baik tidak dengan cara yang penuh dengan paksaan, ketika anak merasa dihargai dan di didik dengan cara yang lebih baik akan menolong anak berkembang dan memiliki pertumbuhan yang baik.

Pendidikan anak dalam keluarga dan lingkungan dimana dia dibesarkan sangat mempengaruhi kepribadian seorang anak dalam bergaul, jika anak dibesarkan dalam keluarga yang baik dan dibesarkan dengan kasih sayang yang cukup dan didukung oleh lingkungan yang baik dan sehat, tentu hal ini dapat membentuk kepribadian seorang anak dalam proses kedewasaannya dan pertumbuhan imannya, peran orang tua dan lingkungan sosial berpengaruh dalam pembentukkan kepribadian anak, dimana orang tualah yang pertama menanamkan nilai-nilai pendidikan yang benar kepada anak dan lingkungan sosial tempat mereka dapat mengembangkan nilai-nilai pendidikan yang telah diajarkan.

\section{Kajian Teori}

Teori konvergensi adalah hasil pengabungan atau kerja sama antara interaksi lingkungan dan bawaan. "William Stren (1871-1938) adalah seorang pencetus teori konvergensi dan dikenal sebagai filosof dan psikolog dari jerman, pandangan ini menyatakan bahwa bakat seorang yang di bawa sejak lahir tidak akan berkembang tanpa adanya dukungan dari lingkungan yang sesuai perkembangan bakat anak tersebut."1 Jika seorang anak memiliki kecerdasan intelektual yang baik dan merupakan turunan dari orang tua mereka akan tetapi lingkungan dimana tempat ia berada tidak mendukung kecerdasannya maka dengan sendirinya akan hilang, begitupun sebaliknya .

"Menurut Francis Galton (1822-1911) mengatakan jika dua orang anak kembar identik jika mereka dididik dan dibesarkan dalam keluarga dengan lingkungan yang berbeda akan mengembangkan sifat-sifat yang berbeda pula. Makin besar perbedaan lingkungannya, maka makin besar pula perbedaan sifat kedua anak itu (dalam Bulmer, 2003)."2 Lingkungan akan mempengaruhi perubahan sifat kepada anak kembar ini misalnya lingkungannya buruk maka sifat anak ini akan buruk, dan jika lingkungannya baik maka baik pula sifat anak. Tidak bisa di pungkiri bahwa lingkungan sangat berperan penting dalam pembentukan karakter anak.

William stern belum menjelaskan seberapa besar pengaruh dari kedua faktor dalam dan luar, dan kedua faktor ini belum dapat di tetapkan. "para psikolog sudah melakukan penelitian mengenai faktor tersebut, faktor pembawaan : faktor ini lebih menentukan hal intelgensi, fisik, pengindraan, sedangkan faktor lingkungan: lebih menentukan pembentukkan kebiasaan, kepribadian dan nilai-nilai kejujuran,

${ }^{1}$ Sarlito W. Sarwono, Pengantar Psikologi Umum (Jakarta: Katalog Dalam Terbitan, 2017),168.

${ }^{2}$ Sarwono. 
kegembiraan, sedih dan ketergantugan terhadap orang lain."3faktor pembawaan dan faktor lingkungan saling berhubungan, jadi jika faktor pembawaan atau bakat tidak diasa dalam sebuah lingkungan maka bakat tersebut tidak akan berkembang, begitu juga sebaliknya dengan lingkungan, jika tidak ada bakat yang dikembangkan maka lingkungan tidak akan berperan,

"Menurut Stanley Health berkata, manusia adalah makhluk sosial yang saling berdampingan, manusia adalah makhluk sosial yang harus berkomunikasi dan seseorang memerlukan dua konteks sosial, yaitu keluarga dan lingkungan sosial."4 Manusia adalah makhluk sosial yang saling hidup berdampingan dan peran keluarga dan lingkungan sama-sama saling menguntungkan. Lingkungan adalah sebuah tempat belajar dan berkembangnya bakat seorang anak, tergantung dari lingkungan sekitarnya jika pengaruhnya baik maka hasilnya akan baik sebaliknya jika pengaruhnya buruk maka hasilnya akan buruk juga.

Pendidikan adalah penanaman nilai-nilai karakter dan kepribadian, perkembangan ini dapat dilakukan dengan seorang diri "manusia hidup di dalam lingkungan sosial dan hal ini membantu anak tersebut, untuk dapat mengembangkan nilai-nilai karakter dan kepribadian yang di miliki, dan lingkungan sosial mempengaruhi kedewasaan anak tersebut." Menjadi penting bagi kita mengetahui bahwa manusia membutuhkan lingkungan yang dapat membantu perkembangan kepribadian anak untuk menjadi lebih baik, agar nilai-nilai yang di tanamkan orang tua dari sejak lahir dapat di praktekan dan menjadikan kepribadian anak lebih dewasa.

Lingkungan mempengaruhi kepribadian dan karakter seorang anak, dan keluarga harus memperhatikan lingkungan tempat anak itu bergaul, sebab lingkungan yang sehat dapat mempengaruhi perbuatan,sikap,karakter serta kepribadian anak tersebut. "Karakter terbagi menjadi 3 bagian yang saling terhubung, baik itu moral knowing yaitu pengetahuan, moral feeling yaitu perasaan dan moral behavior yaitu perilaku moral, tiga hal ini yang harus dapat di miliki dalam diri seorang anak dan moral ini di dapat, di dalam lingkungan pendidikan." 6

Pendidikan moral mempengaruhi karakter dan kepribadian seorang anak "sebab karakter adalah ciri khas dan perilaku sosial yang ditunjukkan melalui sifat,perbuatan dan cara beradaptasi seorang anak, dan ini lah yang mendorong seorang individu untuk berani bertindak dan bertanggung jawab dalam perbuatannya hal inilah yang menjadi motivasi untuk mendewasakan kepribadian seorang anak tersebut." ${ }^{, 7}$ Pendidikan karakter berperan

\footnotetext{
${ }^{3}$ Musdalifah, "Peserta Didik Dalam Pandangan Nativisme, Empirisme, Dan Konvergensi," Jurnal Idaarah 20182 No.2, no. 243-251 (n.d.): 248. http://journal.uinalauddin.ac.id/index.php/idaarah/article/view/243-251

${ }^{4}$ Rida Sinaga, "Pendidikan Karakter Pada Anak Usia Dini," Jurnal Societes Dei 20185 No.2, no. 181-200 (n.d.): 181. http://www.societasdei.rcrs.org/index.php/SD/article/view/89

${ }^{5}$ Nopan Omeri, "Pentingnya Pendidikan Karakter Dalam Dunia Pendidikan," Jurnal Manajer Pendidikan 20159 No.1, no. 464-468 (n.d.): 466. https://ejournal.unib.ac.id/index.php/manajerpendidikan/article/view/1145/0

${ }^{6}$ Muhammad Ali Ramdani, "Lingkungan Pendidikan Dalam Implementasi Pendidikan Karakter," Jurnal Pendidikan Universitas Garut 20148 No.1, no. 28-37 (n.d.): 29. https://journal.uniga.ac.id/index.php/JP/article/view/69/70http://journal.uniga.ac.id/index.php/JP/article/vi ew/69/70

${ }^{7}$ Deny Setiawan, "Peran Pendidikan Karakter Dalam Mengembangkan Kecerdasan Moral,' Jurnal Pendidikan Karakter 20133 No.1, no. 53-61 (n.d.): 55. https://journal.uny.ac.id/index.php/jpka/article/view/1287/1071
} 
dalam mendorong kepribadian seorang anak untuk bertanggung jawab, keluarga dan lingkungan lah yang sama-sama berperan dalam perkembangan moral anak.

Keluarga dan lingkungan sosial sama-sama memiliki peran untuk mengembangkan kepribadian seorang anak, khusus dalam hal prestasi yang capai anak. "Keluarga adalah lembaga utama yang mendorong anak untuk untuk mencapai prestasi yang ingin di capainya, sedangkan lingkungan sosial lah yang menjadi tempat bagi seorang anak untuk mengembangkan prestasi yang menjadi keunggulannya, dengan belajar banyak dari apa yang telah di lihat dan di dengar, lingkungan sosial yang memunculkan suatu proses interaksi sehingga bakat atau keunggulan yang di miliki anak tersebut dapat dikembangkan dengan baik dan menghasilkan prestasi yang memuaskan."

pendidikan dalam keluarga adalah hal yang pertama di ingat oleh anak, sebab ketika mereka sudah keluar dari dalam lingkungan keluarga mereka akan masuk ke dalam lingkungan yang baru dan mereka akan melihat hal-hal baru ditemui, salah satunya adalah kenakalan yang akan merusak moral, karakter dan kepribadian anak tersebut. Itu sebabnya anak perlu mengetahui nilai-nilai yang baik yang telah ditanamkan dalam dirinya. "pendidikanlah yang membantu seseorang untuk memahami dan menyesuaikan diri dengan lingkungan, pendidikan juga merupakan kebutuhan utama yang dapat mengatasi segala perbuatan yang buruk dan mengajarkan hal-hal yang baik tergantung dari didikan dan ajaran yang telah di alami dalam lingkungannya sendiri baik itu keluarga dan juga lingkungan sosial tempat anak itu berinteraksi dan menjalani kehidupannya."9

"Menurut Tamara 2016 dan Subinto 2013, lingkungan sosial mempunyai peranan penting memiliki upaya dalam mengubah cara pandang peserta didik dan memberikan nilai-nilai kecintaan terhadap lingkungan agar terbentuknya karakter yang peduli."10 Mausia adalah makhluk sosial dalam kehidupannya dan lingkungan adalah tempat di mana mereka mempratekannya untuk menmiliki karakter yang baik apalagi meberikan kontribusi untuk lingkungan agar terus asri sehingga lingkungan dapat menjadi obyek perubahan sikap dan tindakan perubahan karakter anak.

"Keluarga khususnya orang tua mempunyai peranan di dalam pertumbuhan dan perkembangan pribadi seorang anak. Sebab menurut Soelaeman (1994:24) orang tua merupakan lingkungan pertama dari tempat kehadirannya dan mempunyai fungsi untuk menerima, merawat dan mendidik seorang anak."11 Dalam hal ini orang tua mendidik anak untuk terus berkembang dan memiliki tempat penanaman nilai-nilai pembelajaran agar di pakai dalam pembentukan pribadi seorang anak pada usia dini.

\footnotetext{
${ }^{8}$ Didik Kurniawan and Dhoriva Urwatul Mustqa, "Pengaruh Perhatian Orang Tua, Motivasi Belajar, Dan Lingkungan Sosial Terhadap Prestasi Belajar Matematika Siswa Smp," Jurnal Riset Pendidikan Matematika 20141 No.2, no. 177-187 (n.d.): 178. https://journal.uny.ac.id/index.php/jrpm/article/view/2674/2227

${ }^{9}$ Wuwuh Yunhadi, "Peranan Pendidikan Keluarga Dalam Mengurangi Kenakalan Remaja.," Jurnal Pendidikan Dan Pembelajaran 20161 No.1, no. 1-11 (n.d.): 3. http://mediailmu.org/index.php/mediailmu/article/view/5/1

${ }^{10}$ Fitria Mustika and Tengku Muhammad Sahundra, "Peranan Lingkungan Sosial Terhadap Pembentukan Karakter Peduli Lingkungan Mahasiswa Pendidikan Geografi Di Universitas Samudra Langsa," Jurnal Pendidikan Ilmu-Ilmu Sosial 201810 No.2, no. 235-244 (n.d.): 237. https://jurnal.unimed.ac.id/2012/index.php/jupiis/article/view/11291/10198

${ }^{11}$ Tri Rosana Yulianti, "PERANAN ORANG TUA DALAM MENGEMBANGKAN KREATIVITAS ANAK USIA DINI," Empowerment, Jurnal Ilmiah Pendidikan Luar Sekolah 3, No.1 2014, no. 1-14 (n.d.): 3. http://ejournal.stkipsiliwangi.ac.id/index.php/empowerment/article/view/569/386
} 
"Orang tua adalah sebuah keluarga yang terdiri dari ayah dan ibu, dan merupakan sebuah ikatan perkawinan yang sah yang dapat membentuk sebuah keluarga. Orang tua memiliki tanggung jawab untuk mendidik, mengasuh dan membimbing anak untuk mencapai masa depan anak dan yang menghantarkan anak untuk siap bersosialisasi di kehidupan bermasyarakat." 12 Menjadi orang tua yang sukses dalam mendidik anak dalam keluarga merupakan idaman semua oang tua namun jika orang tua tidak memiliki tanggung jawab yang besar dalam mendidik anak dengan upaya menanamkan norma untuk anak mencapai masa depan anak yang baik terjadi dalam keluarga sehingga anak dapat bersosialisasi dengan orang-orang yang ada di sekelilingnya.

"Kasih adalah kebutuhan (need) dasar anak. Anak memerlukan kasih tidak hanya pada masa pembentukannya saja, tetapi disepanjang hidup anak. Untuk itu orang tua hams dapat memenuhi kebutuhan anak akan kasih dan dapat dilakukan dengan sentuhan fisik, dekapan, pelukan, dan sanjungan. Kasih diberikan kepada anak dalam bentuk kontak fisik maupun verbal."13 Dalam hal ini orang tua harus memberikan kasih yang adalah kebutuhan dasar dari pembentukan karakter anak bukan hanya sekali namun sepanjang kehidupan anak itu orang tua memberikan yang adalah kebutuhan dasar anak baik secara formal maupun verbal. Apa yang di tanamkan orang tua menjadi landasan anak untuk berbagi kepada orang lain dalam hubungannya dengan masyarakat atau lingkungan sekitar dimana tempat ia berada.

“(Paulus Lilik Kristianto, 2016), mengatakan bahwa "keluarga merupakan tempat untuk memberi energi, perhatian, komitmen, kasih dan lingkungan yang kondusif untuk bertumbuh di dalam iman bersama Tuhan." 14 tujuan dari keluarga adalah mengembangkan seluruh perkembangan anak secara holistic dengan perubahan kognitif, afektif, dan psikomotor agar dalam masyarakat anak dapat bertumbuh bersam-sama dengan orang lain dengan lingkungan yang sama untuk terus bertumbuh dalam iman kepada Tuhan.

\section{Alasan literatur dan pengunaan Alkitab}

Tujuan penggunaan Alkitab dalam 1 Samuel 1-3:4a untuk mendukung teori konvergensi ,karna cerita di dalam nats tersebut sangat mendukung untuk menjelaskan peran atau pengaruh dari teori konvergensi. 1 samuel 1-3:4a menjelaskan bagaimana Samuel yang sudah diajarkan atau ditanamkan hal-hal baik oleh orang tuanya "ibunya" dan itu membuat Samuel dapat bertumbuh dengan baik, dan menjadi anak yang taat. Samuel mendapat banyak dorongan atau didikan dari imam Eli yang membuat Samuel semakin bertumbuh, secara khusus kerohaniannya dan Samuel menjadi pelayan Tuhan yang luar biasa.

Sumber yang digunakan terdapat dalam kitab 1 Samuel 1-3:4a, alasannya dalam teks ini terhubung dengan teori konvergensi dan tergantung nilai-nilai yang terkandung di

\footnotetext{
${ }^{12}$ Noormala Rachmawati, dkk, "Psychological Well Being Ditinjau Dari Keberadaan Orang Tua Pada Remaja Yang Tinggal Di Panti Asuhan,” Persona Jurnal Psikologi Indonesia 8, No. 1, 2019, no. 117 (n.d.): 7. http://jurnal.untag-sby.ac.id/index.php/persona

${ }^{13}$ Hendra Vitaurus, "Peran Orang Tua Dalam Menerapkan Kasih Dan Disiplin Kepada Anak Usia 2-6 Tahun Sebagai Upaya Pembentukkan Karakter," Kurios (Jurnal Teologi Dan Pendidikan Agama Kristen) 3, No. 1, Oktober 2015, no. 1-18 (n.d.): 5. http://www.sttpb.ac.id/e-journal/index.php/kurios

${ }^{14}$ Talizaro Tafonao, "PERAN PENDIDIKAN AGAMA KRISTEN DALAM KELUARGA TERHADAP PERILAKU ANAK,” Edudikara: Jurnal Pendidikan Dan Pembelajaran, Vol 3 (2), 2018 Vol 3 (2), 2018 (n.d.): 4. http://ojs.iptpisurakarta.org/index.php/Edudikara/article/view/92/69
} 
dalamnya. Sehubungan dengan teori yang di paparkan bahwa jika lingkungan keluarga baik maka pada saat di masyarakat yang baik pula akan terjalin terus dengan baik. Hal ini dipengaruhi oleh lingkunya dimana ia berada. "Samuel adalah seorang anak dari suku Efraim asal rama ( I Sam, 1:1) dan menurut I Taw. 6:13 ia adalah seorang keturunan suku Lewi." 15 Kita tahu bahwa secara umum, suku bangsa Lewi ditugaskan untuk menolong para Imam di rumah ibadat atau di rumah Allah (Bil 3:1-13).

Pengunaan Alkitab dalam teori ini di dasarkan pada pengajaran-pengajaran yang berhubungan dengan pendidikan kristen yang berfokus pada tujuan untuk mendidikan dan menjelaskan tentang pentingnya arti kebenaran. "pendidikan Kristen memiliki tujuan yaitu untuk mengajar, mendidik dan membentuk seseorang agar dapat mengenalkan arti kebenaran akan Kristus Yesus." 16 Alkitab adalah sumber yang terpenting dalam mengajarkan kebenaran dan pentingnya pendidikan Kristen bagi semua orang-orang percaya. Dalam lingkungan keluarga kristen didikan yang diberikan orangtua kepada anak selalu berpatokan kepada Firman Tuhan, hal ini bertujuan agar apa yang telah di ajarkan dan ditanamkan orangtua kepada anak, melalui pengajaran Kristen dapat memberi perubahan dan dampak kepada anak, untuk lebih siap menghadapi lingkungan baru yang akan ditemui olehnya.

Alkitab banyak mengajarkan hal-hal yang berkaitan tentang pendidikan dalam keluarga yang memotivasi keluarga kristen untuk hidup berkenan dihadapan Allah, pengunaan Alkitab berperan untuk membentuk akhlak, perilaku dan kepribadian manusia. Keluarga adalah peran utama dalam pembentukan bakat dan kepribadian di dalam diri seorang anak, "lingkungan keluarga berperan dalam terbentuknya pertumbuhan nilai-nilai jasmani dan rohani anaknya, keberhasilan dan tidaknya seorang anak ketika mereka bertumbuh bergantung pada pengajaran yang di terapkan dalam lingkungan keluarga tersebut."17

\section{Hubungan Nas Alkitab Dengan Teori}

Narasi dari kitab 1 Samuel 1:1-28 ${ }^{18}$ merupakan latar belakang siapa Samuel hingga menjadi seorang yang di pakai Tuhan dengan luar biasa. Kelahiran Samuel merupakan syukur bagi Hana yang adalah ibu Samuel yang mengalami kemandulan. Samuel lahir di keluarga yang baik hingga pada masa pembentukkan kepribadian Samuel, Samuel diberikan dan diserahkan kepada Imam Eli untuk dididik menjadi pelayan Tuhan. sebagaimana kita tahu bahwa konvergensi adalah penemuan titik dari pertemuan antara pembawaan dan lingkungan. Dapat dikatakan jika pembawaan yang didapat dari kelahiran Samuel ditengah-tengah kedua orang tua yang melayani Tuhan dalam hal ini lingkungan yang di berikan juga membantu untuk mengaktualisasikan dirinya menjadi lebih baik.

Di dalam narasi 1 Samuel 3:1-4a menceritakan kehidupan Samuel saat menjadi pelayan Tuhan di bawah pengawasan imam Eli dan juga pertemuan pertama antara Allah dan Samuel dimana Allah memanggil Samuel untuk menyampaikan sebuah nubuatan

\footnotetext{
${ }^{15}$ Alkitab (Jakarta: Lembaga Alkitab Indonesia, 2011).

${ }^{16}$ Simon Runtung, "Pendidikan Kristen Dalam Pelayanan Pengembalaan," Jurnal Jaffray: Jurnal Teologi Dan Studi Pastoral 20053 No.1, no. 31-40 (n.d.): 32. https://ojs.sttjaffray.ac.id/index.php/JJV71/article/view/140

${ }^{17}$ Wenny Hulukati, "Peran Lingkungan Keluarga Terhadap Perkembangan Anak," Jurnal Musawa 20157 No.2, no. 265-282 (n.d.): 266. https://media.neliti.com/media/publications/114008-IDperan-lingkungan-keluarga-terhadap-perke.pdf

${ }^{18}$ Alkitab.
} 
tentang apa yang akan Allah lakukan kepada keluarga Eli. Tetapi Samuel sempat segan untuk memberitahukan apa yang Tuhan sampaikan kepada dia, tetapi imam Eli mengajarkan kepada Samuel untuk berkata jujur dan pada akhirnya Samuel memberitahukan kepada imam Eli tentang apa yang Allah sampikan kepadanya. Hubungannya dengan teori konvergensi adalah imam Eli mengajarkan kepada Samuel untuk menjadi anak yang berani dalam menyampaikan segala sesuatu yang Tuhan sampaikan kepadanya, dan akhirnya Samuel belajar untuk berkata jujur (1 Samuel 3:17).

Pada teori sebelumnya di jelaskan bahwa antara pembawaan dan lingkungan mempunyai peran masing-masing dalam pembentukan kepribadian anak. "Seseorang dengan

taraf kecerdasan yang tergolong terbelakang jika di beri didikan yang sistematis untuk menguasai pelajaan-pelajaran sekolah menengah tidak akan menunjukan kemajuan yang berarti sampai masa percobaan usai."19 dapat di jelaskan bahwa pembawaan tidak akan menjadi salah satu dorongan untuk dapat berubah dari kepribadian anak yang jahat menjadi baik jika tidak ada lingkungan baik yang dapat menjadi pengembangan kepribadian dari anak itu sendiri. Begitupun dengan Samuel jika Hana hanya menyerahkan Samuel kepada Imam Eli dengan harapan menjadi pelayan untuk dididik menjadi anak yang takut akan Tuhan, maka pengharapan dari penyerahan Samuel kedalam tangan Tuhan hanya sia-sia saja, jika tidak ada lingkungan di sekelilingnya yang menjadi acuan Samuel untuk belajar kebenaran Firman Tuhan. Bait Allah menjadi pendorong untuk Samuel dapat mengembangkan kepribadiannya untuk terus melayani Allah di bawah pengawasan Imam Eli.

\section{Metode}

Metode penulisan makalah ini adalah analisis data kualitatif yaitu menjelaskan data-data yang dikumpulkan sesuai dengan teori-teori yang dirangkum dari hasil penelitian. ${ }^{20}$ Selanjutnya dengan menggunakan model pembelajaran kooperatif berbasis media sosial. ${ }^{21}$ Dengan menggunakan metode 5P (Belajar berarti berubah) ${ }^{22}$ dengan tujuan untuk meningkatkan nilai-nilai karakter pada kecedasan anak usia dini. ${ }^{23}$

5 P:

\section{Penghubung}

Dalam metode ini kami menghubungkan teori ini dengan cerita dari kitab 1 Samuel 1-2:4a dengan Drama singkat.

\section{Pengajaran}

\footnotetext{
${ }^{19}$ Sarwono, Pengantar Psikologi Umum hal 169.

${ }^{20}$ Hengki Wijaya and Helaluddin Helaluddin, Analisis Data Kualitatif Sebuah Tinjauan Teori \& Praktik (Makassar: Sekolah Tinggi Theologia Jaffray Makassar, 2019).

${ }^{21}$ Hengki Wijaya and Arismunandar Arismunandar, "Pengembangan Model Pembelajaran Kooperatif Tipe STAD Berbasis Media Sosial," Jurnal Jaffray 16, no. 2 (October 6, 2018): 175-96, https://doi.org/10.25278/jj71.v16i2.302.

${ }^{22}$ Roland Walker, "Learning That LASTS," n.d., https://wycliffe.fi/wpcontent/uploads/2018/12/intro-to-learning-that-lasts-walker.pdf.

${ }^{23}$ Hengki Wijaya and Helaluddin Helaluddin, "Hakikat Pendidikan Karakter," 2018, https://repository.sttjaffray.ac.id/id/publications/269450/hakikat-pendidikan-karakter.
} 
Teori yang kami gunakan adalah teori Willam Stren mengatakan bahwa "hasil pendidikan anak di pengaruhi dua faktor yaitu pembawaan dan lingkungan." 24 Dalam cerita Samuel pendidikan yang di dapat melalui dua faktor yaitu pembawaan dan lingkungan sangan membantu untuk pembentukan kepribadian Samuel menjadi lebih taat kepada Tuhan.

"Keluarga adalah unit terkecil dalam masyarakat yang terdiri dari suami istri, atau suami istri dan anaknya, atau ayah dan ananya, atau ibu dan ananya, atau keluarga segaris lurus atau ke bawah denga derajat ketiga. Menurut Beni Ahmad Saebani dan Hedra Akhdiyat (2019:262) "Lingkungan adalah ruang dan waktu yang menjadi tempat eksistensi manusia. Lingkungan mencakup iklim dan geografis, tempat tinggal dan adat istiadatt dan pengetahuan pendidikan dan alam dengan kata lain lingkungan ialah segala sesuatu yang tampak dan terdapat dalam alam kehidupan yang senantiasa berkembang, ia adalah seluruh yang ada, baik manusia maupun benda buatan manusi atau alam yang bergerak dengan kejadian atau hal-hal yang mempunyai berhubungan dengan seseorang." 25 Dapat disimpulkan bahwa keluarga dan lingkungan adalah tempat pendidikan anak untuk mengarahkan kepribadian yang lebih baik. Kita melihat dari cerita Samuel ini bagaimana Hana menitipkan Samuel kepada Imam Eli untuk di bina menjadi anak yang bertanggung jawab dalam tugasnya melayani Allah.

\section{Perubahan}

Yang diharapkan dalam perubahan dari siswa adalah siswa dapat menceritakan bagaimana teori ini berkesinambungan dalam kehidupan sehari-hari dari kecil sampai sekarang dimana tempat ia berada di tingkat yang tinggi.

\section{Penerapan}

Diharapkan siswa mendapat perubahan setelah menerapkan teori konvergensi siswa mengalami perubahan secara keseluruhan (holistic) adanya perubahan dari pemahaman (kognitif) siswa tentang teori yang disampaikan, kemudian perasaan (afektif) dan membuat perliaku ( psikomotor) anak menjadi pribadi yang lebih baik

\section{Penutup}

Menuliskan komitmen didalam kertas kecil dan ditaruh didalam Alkitab, buku atau diary dimana mereka dapat melihat dan mengingatnya selalu.

\section{BAB III}

\section{Hasil dan Pembahasan}

Penulisan ini mengambil sebuah peran orang tua dan lingkungan sosial terhadap pembentukan kepribadian anak. Hal ini berlandaskan pada teori konvergensi bagaimana pengaruh dari keluarga dan juga lingkungan yang mengembangkan bakat dalam diri seseorang. Tujuan penulisan ini menghubungkan teori konvergensi dan metode 5P yang harus dikembangkan dalam sebuah pembelajaran yang akan disampaikan kepada para

\footnotetext{
${ }^{24}$ amni Leonawarty, "Efek Peran Serta Keluarga Dalam Proses Pendidikan Anak,” Eduka Jurnal, 1 Febuary 2016 vol 1, no. 1-11 (n.d.).

${ }^{25}$ Ahmad Izzuddin, "Implikasi Lingkungan Keluaarga Terhadap Pembentukan Kepribadian Siswa SDN 4 Gunung Rajak," Fondatia: Jurnal Pendidikan Dasar, 2018 2, No. 1, no. 1-29 (n.d.): 14142.
} 
peserta didik. Dalam keluarga orang tua harus melihat bakat alami yang dimiliki oleh seorang anak, dan bakat ini juga harus dikembangkan dengan memberi peluang atau kebebasan kepada seorang anak untuk berbaur dengan lingkungan yang berada disekitarnya, agar lingkungan juga berperan dalam mempengaruhi potensi, kepribadian dan bakat yang di miliki anak tersebut.

Orang tua juga perlu memperhatikan apa yang diajarkan kepada anak tersebut, sebab anak juga dapat mengingat apa yang telah di lihatnya dan itu mempengaruhi kepribadian anak tersebut. Baik atau buruknya pendidikan yang disampaikan kepada anak itulah yang akan mempengaruhi kepribadian dan juga perilaku anak tersebut. Metode 5P sangat berguna dan akan coba untuk diterapkan baik dalam ruang lingkup keluarga dan juga ruang lingkup sekolah, hal ini bertujuan untuk melihat sejauh mana anak dapat berkembang dan apakah metode ini, dapat mempengaruhi pola hidup dan tujuan apa yang akan dilakukan pada masa yang akan datang.

Dalam penulisan ini bertujuan untuk melihat sejauh mana metode 5P ini dapat dikembangkan di dalam ruang lingkup keluarga dan lingkungan sosial. Hal ini juga bertujuan dalam melihat perkembangan apa yang akan di alami anak, ketika ia berada di lingkungan sosial apakah ia mampu menyesuaikan diri dengan lingkungan sekitarnya, dan apakah ia mampu mengembangkan bakat yang di milikinya sehingga anak bisa mencapai prestasi yang baik. Kepribadian anak perlu dibentuk melalui keluarga sebab peran keluarga adalah yang pertama di dalam lingkungan anak tersebut, jika lingkungan keluarga sudah mampu membentuk kepribadian,sikap,karakter yang ada di dalam anak itu. maka dengan otomatisnya anak akan dengan mudah beradaptasi dengan lingkungannya dan mencoba untuk, melihat hal-hal baru yang akan ia pelajari dan dari sinilah anak akan dengan mudahnya, dapat mengembangkan bakat yang di milikinya.

Pendidikan adalah hal yang sangat diperlukan oleh setiap individu, dengan tujuan untuk mencerdaskan setiap kehidupan bangsa. Pendidikan mempengaruhi karakter dan kepribadian seorang anak sebab karakter adalah ciri khas dan perilaku sosial yang ditunjukkan melalui sifat,perbuatan dan cara beradaptasi seorang anak, dan ini lah yang mendorong seorang individu untuk berani bertindak dan bertanggung jawab dalam perbuatannya hal inilah yang menjadi motivasi untuk mendewasakan kepribadian seorang anak tersebut. Motivasi akan mendorong seseorang individu untuk dapat mengembangkan kemampuan serta bakat alami yang di milikinya dan hal ini akan mempengaruhi peran seorang individu untuk berani mengambil langkah dalam mengembangkan bakat alaminya dan mampu berani bertanggung jawab, atas langkahlangkah yang telah di ambil.

\section{Peran lingkungan keluarga}

Lingkungan keluarga memiliki peran utama dalam mendidik seorang anak dan membantu mereka untuk menemukan bakat yang menonjol di dalam diri mereka. Karakter, moral dan kepribadian anak perlu di bentuk sejak awal di dalam keluarga. Orang tua adalah pendidik yang akan mendukung dan mendorong anak untuk menjadi pribadi yang lebih dewasa, jika orang tua tidak mampu menjalankan tugasnya dengan baik maka anak juga, akan kekurangan kasih sayang dan akan merasa bahwa mereka tidak mendapat pendidikan yang baik ketika berada di dalam keluarga. penting bagi kita mengetahui bahwa manusia membutuhkan lingkungan yang dapat membantu perkembangan kepribadian anak untuk menjadi lebih baik, agar nilai-nilai yang di tanamkan orang tua dari sejak lahir dapat di praktekan dan menjadikan kepribadian anak 
lebih dewasa. tujuan dari keluarga adalah mengembangkan seluruh perkembangan anak secara holistic dengan perubahan kognitif, afektif, dan psikomotor agar dalam masyarakat anak dapat bertumbuh bersam-sama dengan orang lain dengan lingkungan yang sama untuk terus bertumbuh dalam iman kepada Tuhan.

\section{Peran Lingkungan Sosial}

lingkungan sosial mempunyai peranan penting memiliki upaya dalam mengubah cara pandang peserta didik dan memberikan nilai-nilai kecintaan terhadap lingkungan agar terbentuknya karakter dan sikap yang peduli. Manusia adalah makhluk sosial dalam kehidupannya dan lingkungan adalah tempat di mana mereka mempratekannya untuk memiliki karakter yang baik apalagi meberikan kontribusi untuk lingkungan agar terus asri sehingga lingkungan dapat menjadi obyek perubahan sikap dan tindakan perubahan karakter anak. Tempat di mana anak dapat mengembangkan bakat dan potensi yang di milikinya adalah lingkungan sosial, karena disinilah mereka akan menemukan jati diri mereka dan banyak mempelajari hal-hal yang baru dan juga akan membentuk kedewasaan dalam diri seorang anak.

lingkungan sosial lah yang menjadi tempat bagi seorang anak untuk mengembangkan prestasi yang menjadi keunggulannya, dengan belajar banyak dari apa yang telah di lihat dan di dengar, lingkungan sosial yang memunculkan suatu proses interaksi sehingga bakat atau keunggulan yang di miliki anak tersebut dapat dikembangkan dengan baik dan menghasilkan prestasi yang memuaskan. Lingkungan sosial inilah yang menjadi tempat bagi mereka untuk beradaptasi dan bergaul, lingkungan ini juga yang mempengaruhi kepribadian seorang anak, jika lingkungannya baik maka hasilnya akan baik dan begitu juga sebaliknya, jika lingkungannya buruk maka pembawaan yang akan di alami anak juga akan buruk.

\section{Kesimpulan}

Lingkungan keluarga merupakan peran utama dalam mengetahui bakat yang menonjol di dalam diri seorang anak, dan juga tempat pertama di mana seorang anak di didik dan ajarkan cara hidup yang baik dalam membentuk kepribadian,karakter, moral di dalam diri anak. Sedang lingkungan sosial tempat anak untuk mengembangkan bakat alami yang di milikinya dan menjadi tempat ia akan belajar banyak hal-hal yang baru yang tentunya akan mendorong seorang anak untuk berani mengambil langkah yang akan ia lakukan demi mencapai prestasi yang akan di raihnya, serta bertanggung jawab terhadap peran dan langkah yang telah di ambilnya.

\section{KEPUSTAKAAN}

Alkitab. Jakarta: Lembaga Alkitab Indonesia, 2011.

Hulukati, Wenny. "Peran Lingkungan Keluarga Terhadap Perkembangan Anak." Jurnal Musawa 20157 No.2, no. 265-282 (n.d.).

Izzuddin, Ahmad. "Implikasi Lingkungan Keluaarga Terhadap Pembentukan

Kepribadian Siswa SDN 4 Gunung Rajak.” Fondatia: Jurnal Pendidikan Dasar, 2018 2, No. 1, no. 1-29 (n.d.).

Kurniawan, Didik, and Dhoriva Urwatul Mustqa. "Pengaruh Perhatian Orang Tua, Motivasi Belajar, Dan Lingkungan Sosial Terhadap Prestasi Belajar Matematika 
Siswa Smp.” Jurnal Riset Pendidikan Matematika 20141 No.2, no. 177-187 (n.d.).

Leonawarty, amni. "Efek Peran Serta Keluarga Dalam Proses Pendidikan Anak." Eduka Jurnal, 1 Febuary 2016 vol 1, no. 1-11 (n.d.).

Musdalifah. "Peserta Didik Dalam Pandangan Nativisme, Empirisme, Dan Konvergensi." Jurnal Idaarah 20182 No.2, no. 243-251 (n.d.).

Mustika, Fitria, and Tengku Muhammad Sahundra. "Peranan Lingkungan Sosial Terhadap Pembentukan Karakter Peduli Lingkungan Mahasiswa Pendidikan Geografi Di Universitas Samudra Langsa.” Jurnal Pendidikan Ilmu-Ilmu Sosial 201810 No.2, no. 235-244 (n.d.).

Omeri, Nopan. "Pentingnya Pendidikan Karakter Dalam Dunia Pendidikan." Jurnal Manajer Pendidikan 20159 No.1, no. 464-468 (n.d.).

Rachmawati, dkk, Noormala. "Psychological Well Being Ditinjau Dari Keberadaan Orang Tua Pada Remaja Yang Tinggal Di Panti Asuhan.” Persona Jurnal Psikologi Indonesia 8, No. 1, 2019, no. 1-17 (n.d.).

Ramdani, Muhammad Ali. "Lingkungan Pendidikan Dalam Implementasi Pendidikan Karakter." Jurnal Pendidikan Universitas Garut 20148 No.1, no. 28-37 (n.d.).

Runtung, Simon. "Pendidikan Kristen Dalam Pelayanan Pengembalaan." Jurnal Jaffray: Jurnal Teologi Dan Studi Pastoral 20053 No.1, no. 31-40 (n.d.).

Sarwono, Sarlito W. Pengantar Psikologi Umum. Jakarta: Katalog Dalam Terbitan, 2017.

Setiawan, Deny. "Peran Pendidikan Karakter Dalam Mengembangkan Kecerdasan Moral." Jurnal Pendidikan Karakter 20133 No.1, no. 53-61 (n.d.).

Sinaga, Rida. "Pendidikan Karakter Pada Anak Usia Dini." Jurnal Societes Dei 20185 No.2, no. 181-200 (n.d.).

Tafonao, Talizaro. "PERAN PENDIDIKAN AGAMA KRISTEN DALAM KELUARGA TERHADAP PERILAKU ANAK.” Edudikara: Jurnal Pendidikan Dan Pembelajaran, Vol 3 (2), 2018 Vol 3 (2), 2018 (n.d.).

Vitaurus, Hendra. "Peran Orang Tua Dalam Menerapkan Kasih Dan Disiplin Kepada Anak Usia 2-6 Tahun Sebagai Upaya Pembentukkan Karakter." Kurios (Jurnal Teologi Dan Pendidikan Agama Kristen) 3, No. 1, Oktober 2015, no. 1-18 (n.d.).

Walker, Roland. "Learning That LASTS," n.d. https://wycliffe.fi/wpcontent/uploads/2018/12/intro-to-learning-that-lasts-walker.pdf.

Wijaya, Hengki, and Arismunandar Arismunandar. "Pengembangan Model Pembelajaran Kooperatif Tipe STAD Berbasis Media Sosial.” Jurnal Jaffray 16, no. 2 (October 6, 2018): 175-96. https://doi.org/10.25278/jj71.v16i2.302.

Wijaya, Hengki, and Helaluddin Helaluddin. Analisis Data Kualitatif Sebuah Tinjauan Teori \& Praktik. Makassar: Sekolah Tinggi Theologia Jaffray Makassar, 2019. . "Hakikat Pendidikan Karakter," 2018. https://repository.sttjaffray.ac.id/id/publications/269450/hakikat-pendidikankarakter.

Yulianti, Tri Rosana. "PERANAN ORANG TUA DALAM MENGEMBANGKAN KREATIVITAS ANAK USIA DINI." Empowerment, Jurnal Ilmiah Pendidikan Luar Sekolah 3, No.1 2014, no. 1-14 (n.d.).

Yunhadi, Wuwuh. "Peranan Pendidikan Keluarga Dalam Mengurangi Kenakalan Remaja.” Jurnal Pendidikan Dan Pembelajaran 20161 No.1, no. 1-11 (n.d.). 